\title{
Geotechnical design considerations for Dugald River - from slot to sequence
}

\author{
R de Vries MMG Limited, Australia \\ R Hassell MMG Limited, Australia \\ J Player MineGeoTech, Australia
}

\begin{abstract}
Concerns regarding the uncertainty of stope dilution at the MMG Limited's Dugald River underground mine led to a trial stoping program to acquire full-scale comprehensive geotechnical information and to test the validity of the geotechnical and mining parameters. A total of 19 stopes were mined by sublevel open stoping with cemented rockfill (CRF). Specific studies were completed on the rock mass response to mining, rock stress and property measurements, stope blast vibration monitoring, production drilling deviation, CRF optimisation, re-logging of diamond core for structural and geotechnical information. Based on the trial stoping results, key geotechnical inputs into mine design and scheduling were provided. These included:
\end{abstract}

- Stope drill and blast parameters such as borehole orientation, explosive type and stope boundary stand-off distances.

- Oredrive and crosscut drive locations to achieve required stope drilling parameters.

- Stope strike length and overbreak predictions.

- CRF optimisation.

- Development through CRF.

- The location and sizing of capital development in relation to orebody and major lithological units.

- Ground support standards based on expected damage from stress.

- Stope sequencing to minimise stress concentrations and location of regional pillars.

The considerable volume of data and the practical experience gained during the trial mining greatly increased the geotechnical knowledge of the rock mass and its response to mining. This allowed for a wide range of geotechnical design considerations to be applied to the project feasibility study at a higher confidence level.

\section{Introduction}

The Dugald River Zn-Pb-Ag deposit is located $85 \mathrm{~km}$ northwest of Cloncurry, Queensland (Figure 1). It is regarded as one of the largest and highest-grade known undeveloped deposits of zinc, lead and silver in the world with a mineral resource of $55 \mathrm{Mt}$ at $13.4 \%$ zinc, $2.1 \%$ lead and $36 \mathrm{~g} / \mathrm{t}$ silver. The deposit was acquired by MMG Limited in 2009 with underground mine development starting in February 2012. The site consists of two underground mines, the north and south mines, due to the lateral extent of the orebody ( $>2 \mathrm{~km}$ along strike). The majority of ore tonnes can be found in the south mine due to greater orebody thickness. The mining method from the 2012 Feasibility Study was sublevel open stoping (SLOS) with a sublevel interval of $25 \mathrm{~m}$ and stope strike length of $25 \mathrm{~m}$. Exposure of the geological conditions in development and additional underground diamond drilling highlighted a more complex and challenging mining environment than predicted in the feasibility study, resulting in the suspension of the project in March 2013. A mining method review (MMR) was completed in mid-2013, which considered SLOS at a 25 m sublevel interval and 
stope strike lengths of $15 \mathrm{~m}$ in the south mine, and an Avoca method in the north mine would be most appropriate. However, the MMR concluded there was an unacceptable level of uncertainty in regards to stope dilution. It was recommended that a trial stoping program be completed to address the main uncertainties regarding stope dilution. Trial stoping commenced in early 2014.

Several geotechnical studies were implemented as part of the trial stoping project to acquire comprehensive geotechnical information and to test the validity of geotechnical parameters for input into mine design.

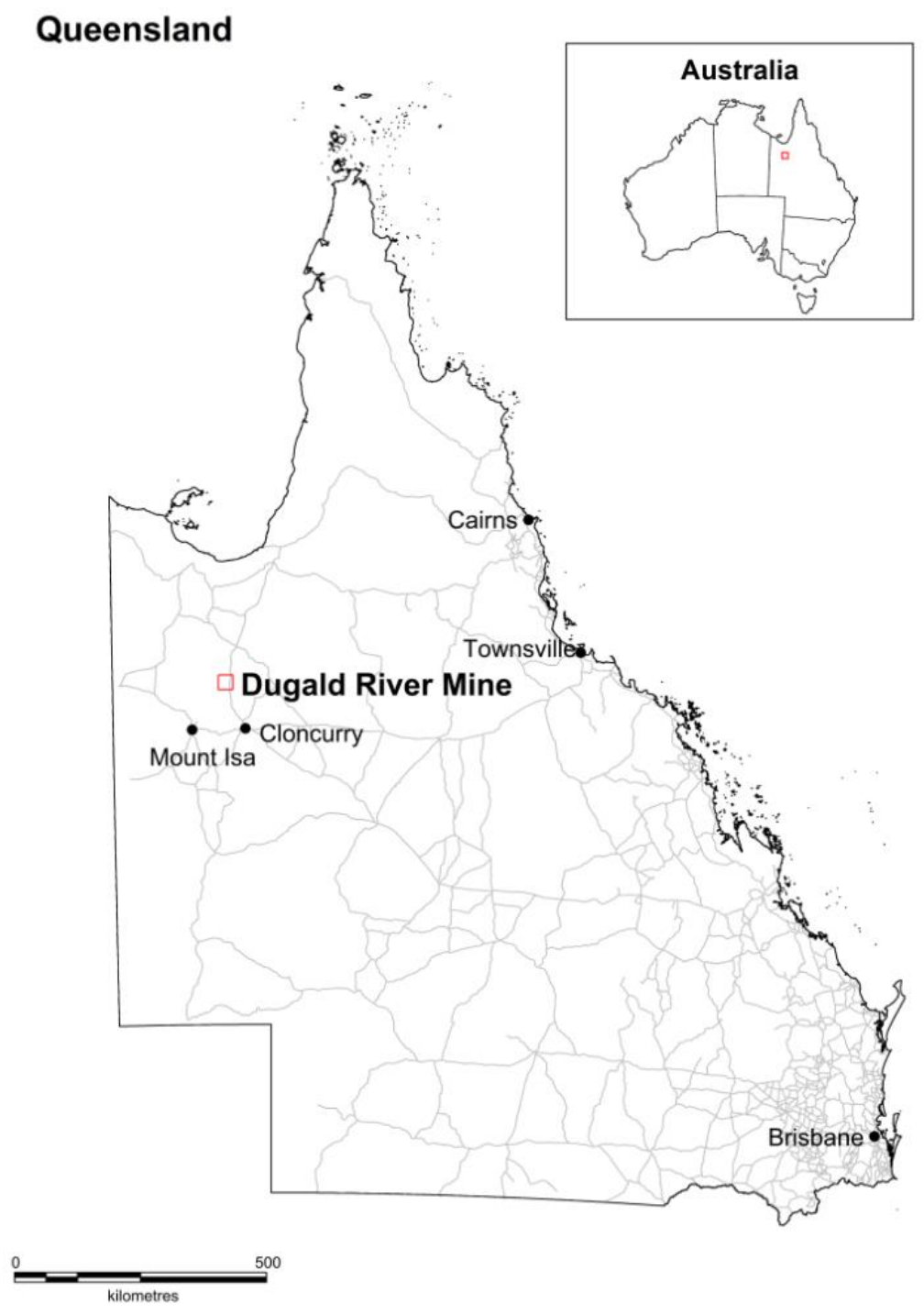

Figure 1 Location of the Dugald River Mine

\section{Geological conditions}

The Dugald River deposit occurs within the eastern fold belt of the Mt Isa Inlier and the Dugald Lode is hosted within a steeply dipping black slate sequence of low metamorphic grade. The deposit is a steep dipping tabular orebody, extending approximately $2 \mathrm{~km}$ along strike and to a depth of approximately $1 \mathrm{~km}$. The orebody strikes approximately north-south (MGN), dips between 45 and $85^{\circ}$ to the west, and varies in horizontal thickness from 2 to $35 \mathrm{~m}$. The area of greatest ore thickness occurs in the central part of the orebody between the depths of 300 and $600 \mathrm{~m}$, which coincides with the area of flattest dip.

The hangingwall (HW) slates (HWSL) occur in the immediate HW of the Dugald Lode and typically vary in thickness between 50 and $100 \mathrm{~m}$. In the area where the Dugald Lode dip flattens to $\angle 50^{\circ}$, the HWSL thickness can be as little as $10 \mathrm{~m}$. Muscovite schist, mafic porphyry and calc-silicates units are found to the 
west of the HW of the HWSL. The HWSL typically consist of massive, fine grained dark grey slate, spotted in places; to laminated, fine grained dark grey to light grey slates, often with carbonate veining. Discontinuity conditions are generally smooth to slickensided with graphite or chlorite infill.

Footwall (FW) slates (FWSL) and limestones (LMST) are located east of the FW of the Dugald Lode. A distinct boundary does not exist between the FWSL and LMST with the FWSL grading into the LMST over a distance of up to $50 \mathrm{~m}$. In some areas, the FW slates are absent and the LMST forms the FW contact with the Dugald Lode. The FWSL's are almost identical in geological and geotechnical parameters to the HWSL's.

The orebody is hosted by slate and is dominated by sphalerite and pyrrhotite/pyrite with minor galena, arsenopyrite and chalcopyrite. It ranges from massive sulphide breccias with large angular clasts of slate to stringer veins hosted in slate.

The area selected for trial stoping at Dugald River is located at shallow depths $(<250 \mathrm{~m}$ below ground surface). The rock mass consists of a steeply west dipping, bedded rock intersected by large scale, potentially weak, geological discontinuities. These features are either sub-parallel to the orebody or crosscut the orebody at shallow angles. The sub-parallel structures are sometimes located within the orebody or the immediate HW of the designed stopes. Structures are variable along strike and down dip, even within a single stope geometry (i.e. $20 \mathrm{~m}$ along strike). The rock mass outside the geological structures can be rated as fair to good, as indicated by the low frequency of discontinuities per metre and the high strength of the intact rock. Average unconfined compressive strength (UCS) of the massive/breccia orebody is approximately $200 \mathrm{MPa}$. The strength of the host rock slates is about $150 \mathrm{MPa}$ with both rock masses having a high modulus.

\section{Original geotechnical model and design considerations}

The original geotechnical domain model assumed a continuous single structure termed the HW shear zone (HWSZ) which varied in thickness and distance from the orebody HW. The domaining only was based on 380 holes with rock quality designation (RQD) and fracture frequency (FF) information. Three risk categories of dilution were identified; within $5 \mathrm{~m}$ of the HWSZ, 5-10 m of the HWSZ and $>10 \mathrm{~m}$ of the HWSZ. For all categories a global equivalent length of overbreak sloughing (ELOS) value of $1.5 \mathrm{~m}$ for the HW was used for the SLOS $25 \times 25 \mathrm{~m}$ stopes.

Exposure of the geological conditions in development and additional underground diamond drilling highlighted a more complex and challenging mining environment than predicted in the 2012 Feasibility Study. A mining method review (MMR) was completed in mid-2013 which concluded that stope dimensions of $25 \mathrm{~m}$ height and $15 \mathrm{~m}$ strike were more appropriate than the feasibility study dimensions. An improved approach of estimating ELOS was applied using the modified $\mathrm{N}$ prime approach similar to that applied at the George Fisher Mine (Capes 2009); a similar strata-bound sediment hosted zinc deposit. Five categories for stope dilution were derived relative to the position of the HWSZ standoff from the lode HW. This method determined an average HW ELOS value of $1.1 \mathrm{~m}$ for SLOS in the south mine and $0.8 \mathrm{~m}$ for Avoca in the north mine. This method also required the use of ore skins of various thicknesses, relative to ground conditions, in areas of poor ground. Values of joint number, roughness and condition were estimated based on underground and diamond drilling exposures relative to the RQD value for the domain within the model. The modifications to the mine design resulted in unfavourable project economics and highlighted the need for improved geotechnical, mining and geological input into mine design, which ultimately led to the trial stoping program.

\section{$4 \quad$ Trial stoping}

In March 2014, a $335 \mathrm{kt}$ trial stoping project commenced in the south mine. The mining method selected was SLOS at $25 \mathrm{~m}$ sublevel intervals, with strike lengths of $15 \mathrm{~m}$. Stope voids were required to be filled with cemented backfill. The aim of trial stoping program was to acquire full-scale comprehensive geotechnical 
information and to test the validity of proposed geotechnical and mining parameters. Three main technical issues were to be addressed:

- Better understand the structural geology and ground conditions in the HW.

- Test that the SLOS mining method and relevant stope dimensions can keep the overbreak (and dilution) under control.

- Test the overbreak prediction method to forecast dilution.

Three areas were identified for trial stoping in the south mine, Zones 5, 6 and 7 (Figure 2) based on proximity to existing underground development and infrastructure; availability of diamond drilling data; and the representativeness of the varying rock mass conditions in the stope HWs compared to the known conditions across the remainder of the orebody.

Zone 6 was ultimately chosen, as at the time the drilling data indicated the most widely representative rock mass conditions. These varied in terms of weak, moderate and good conditions of narrow and medium HWSZ thicknesses as well as offsets from the ore HW boundary. The location did not evaluate wide weak HW conditions as this would have required to also mine Zone 5 (which was not representative of the lode in itself). Zone 6 was also chosen as the cost and time to develop and complete the trial stoping was less than other options, and it presented a range of ore widths from 2 to $25 \mathrm{~m}$.

The sublevel interval was pre-determined at $25 \mathrm{~m}$ due to existing development.

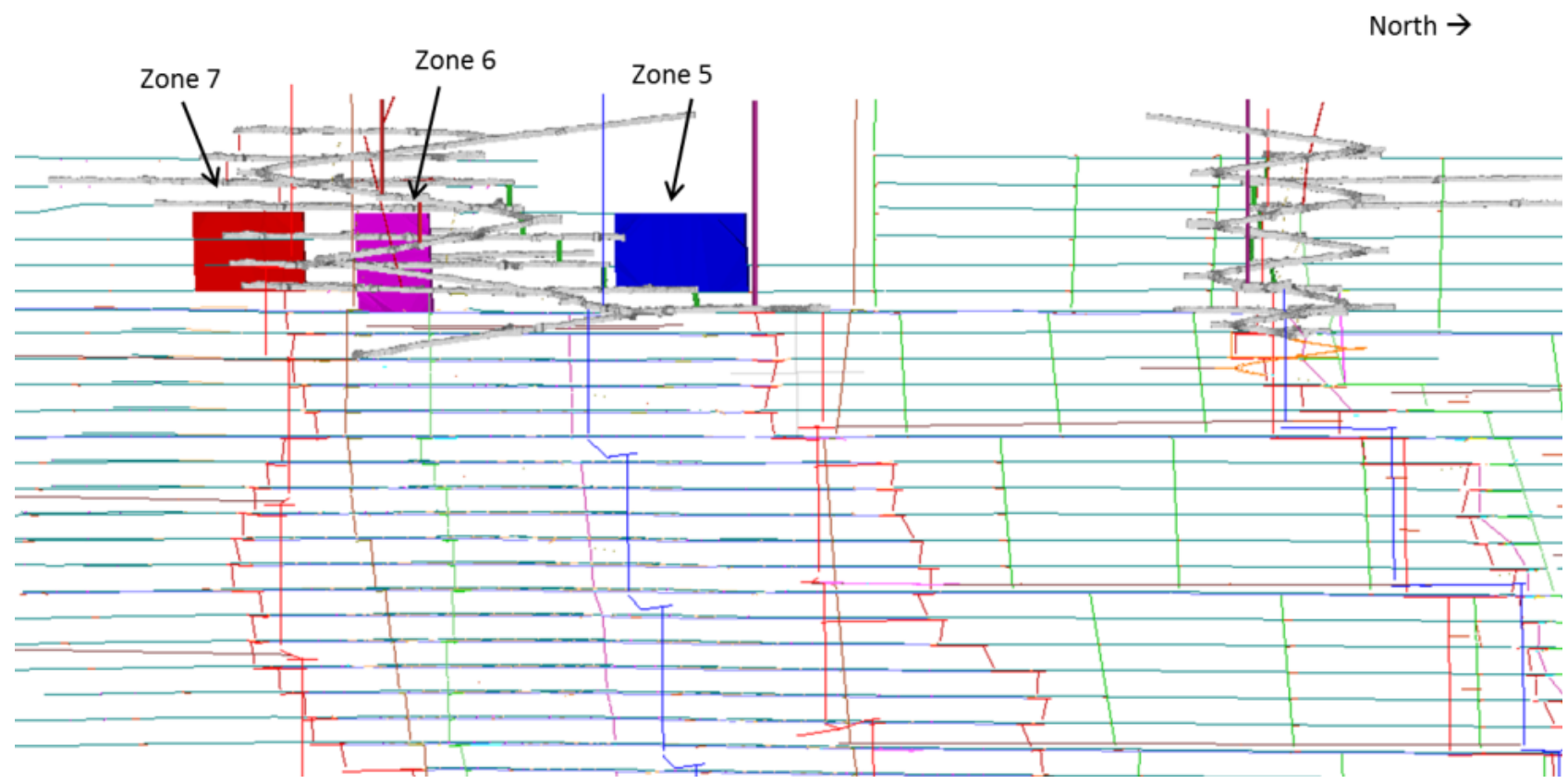

Figure 2 Long section view of three possible mining blocks for trial stoping. Mined development and 2015 LOM design are shown for reference

As more drilling became available in the Zone 6 area, the interpretation of the high grade HW changed. This resulted in upgraded stope shapes and the HW ground conditions were found to be more competent in some areas. Higher drill density and underground development also identified stope offset on shallow west dipping faults and internal orebody faulting where the orebody was thicker. These observations further highlighted the potential geological and geotechnical complexity of mining the Dugald River lode. It became evident that the fault system was much more complex than the singular continuous HWSZ concept.

A bottom up sequence was selected for the trial stoping to test assumptions from the 2012 Feasibility Study, which suggested to mine the orebody in multiple panels as a bottom up sequence retreating to a crown pillar (Figure 3). 


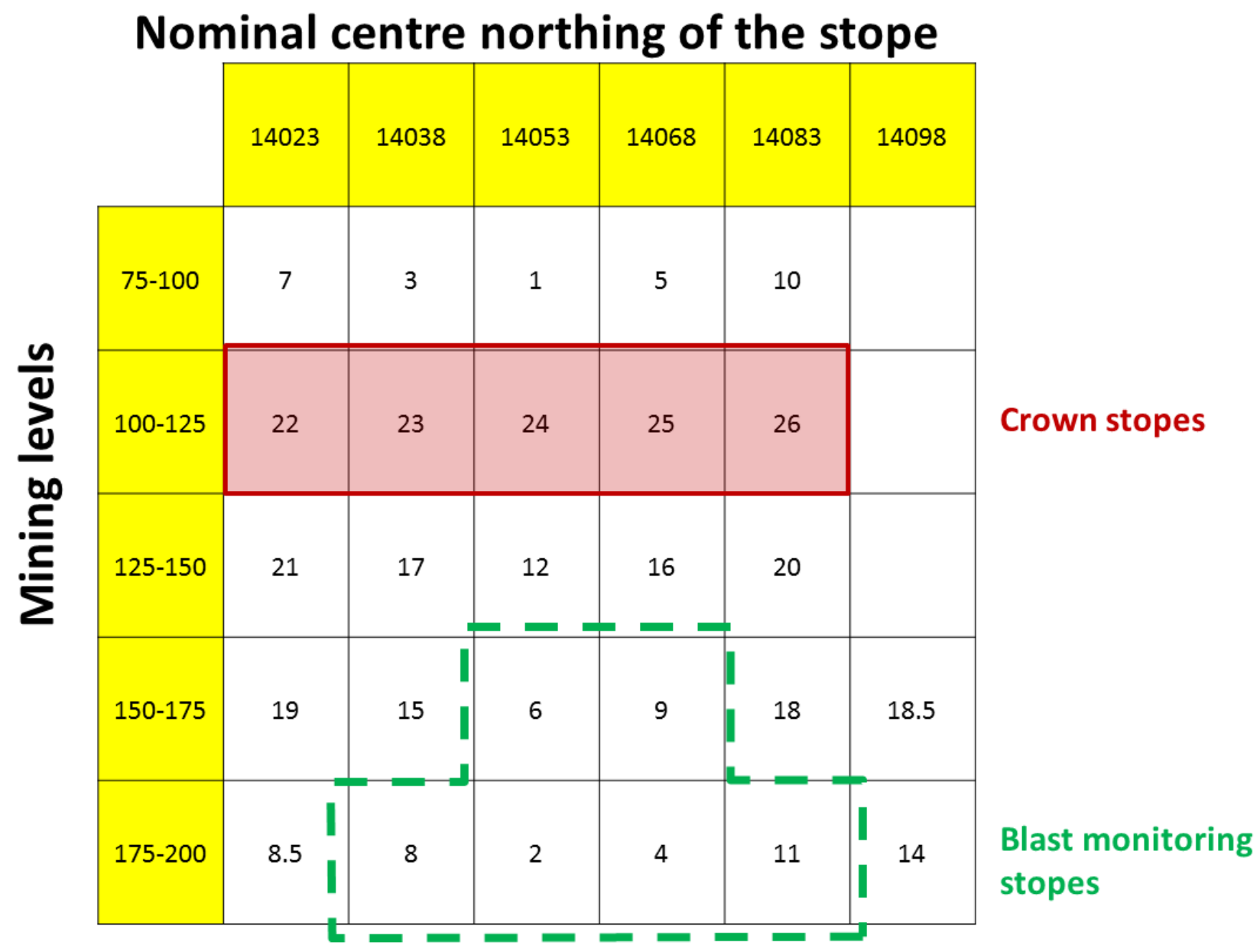

Figure 3 Initial mining sequence for Zone 6 (stope numbers in order of planned extraction sequence)

Changes to the stope sizes and sequence occurred during the early stages of trial stoping as a result of an improved understanding of the Zone 6 ground conditions and favourable stope performance. This will be discussed further in the following section. The trial stoping project successfully mined a total of 19 stopes (Figure 4), which were a combination of longitudinal and transverse stopes, over a period of 10 months, producing $335 \mathrm{kt}$ of ore. 


\section{North $\rightarrow$}

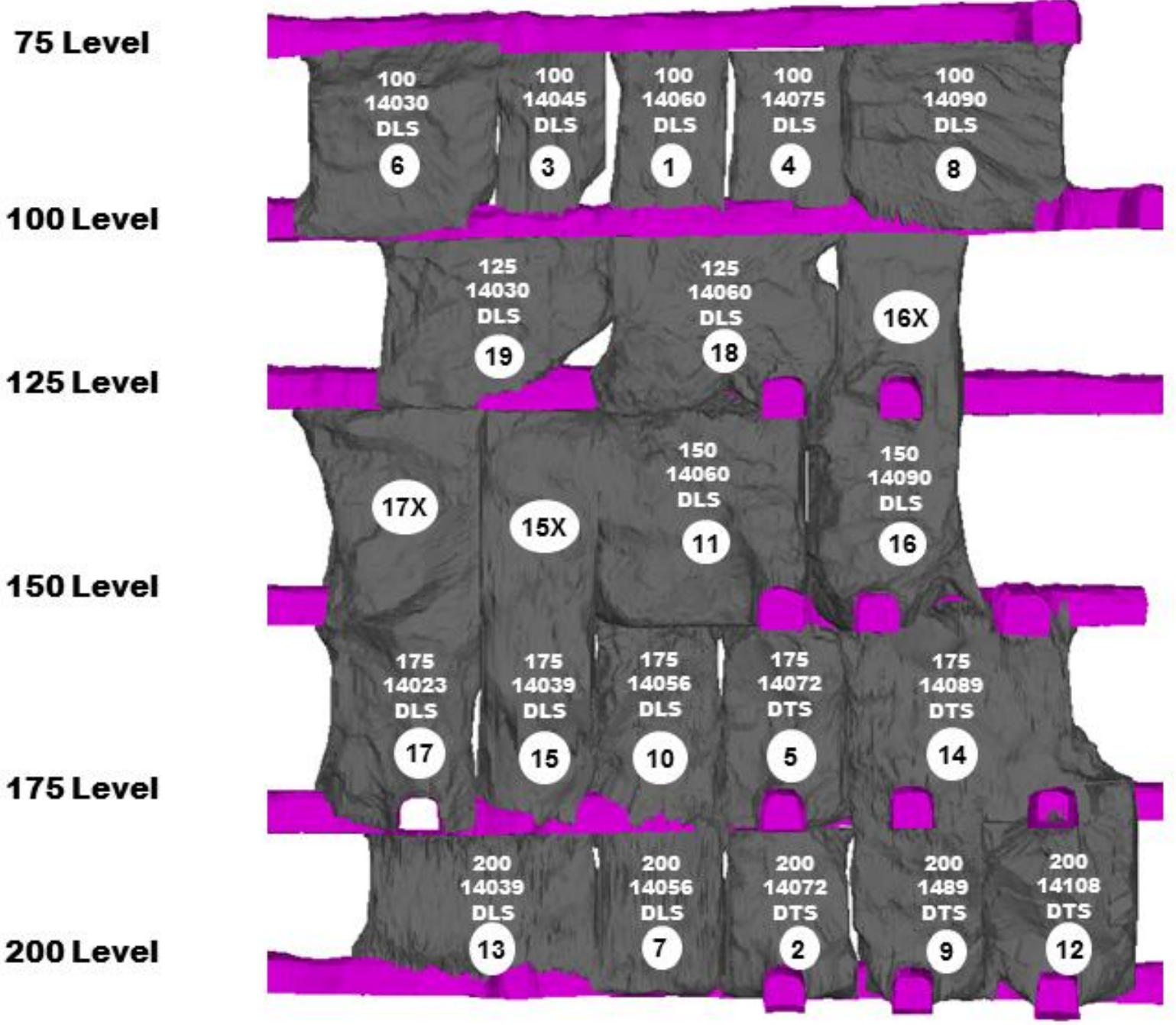

Figure 4 Actual stopes that were mined as part of the trial stoping

\section{$5 \quad$ Specific geotechnical studies as part of the trial stoping}

Various geotechnical studies were carried out as part of the trial stoping project and provided considerable amounts of data for analysis of the trial stoping area. Rock mass behaviour during stoping was intensively studied and was found to be dominated by the frequency and location of HW and orebody crosscutting structures. These structures ranged from millimetre thickness faults to large zones of broken ground and varied in offset distance relative to the stope $\mathrm{HW}$.

\subsection{Geotechnical diamond drill core re-logging}

In March 2013, the geotechnical core logging process was updated to improve geotechnical data collection. Previous site geotechnical core logging data consisted of RQD and fracture frequency logged at metre to metre or core block to core block intervals, which overlooked weak narrow structures that were found to be critical to stope wall stability. The updated logging included:

- Logging carried out by onsite geotechnical engineers.

- Geotechnical domaining of core (with specific focus on narrow weak structures). 
- Logging geotechnical parameters to recognised rock mass characterisation methods, Q (Barton et al. 1974) and $\mathrm{RMR}_{89}$ (Bieniawski 1989).

- Data management, storage and analysis by onsite geotechnical engineers.

This update became the geotechnical site standard for core logging. The update recognised the need to improve collection of the geotechnical input parameters for mine planning and the significance of narrow weak structures in the HW of the stope for rock mass response to excavation. Geotechnical core logging was completed for the orebody and $20 \mathrm{~m}$ either side of the orebody. This was a compromise between available time, resources and quality of logging information required. Re-logging of the historical available core was conducted to ensure geotechnical data was of the same standard for mine scale predictions to dilution from the knowledge gained in the trial stoping. The geotechnical core logging database was increased to 775 holes.

\subsection{Geological structural complexity}

Oredrive development and stope wall observations highlighted a further increase in complexity of the geological structural framework that had not been identified from core logging and interpretation. Faulting was found to offset parts of the orebody, splays were more abundant and anastomosing along strike and down dip was observed. These conditions affected oredrive locations and ultimately stope wall stability in some cases.

Initially a structural review was completed for the Zone 6 area utilising the diamond drill core. Where possible ground truthing of the faults from underground development and stope wall mapping was incorporated. Structural concepts and knowledge were developed from this process. A structural re-logging campaign was then carried out by the geologists on all available core (a total of $65 \mathrm{~km}$ ) which considered the improved structural knowledge (Figure 5). An updated/improved structural model was then developed for the mine.

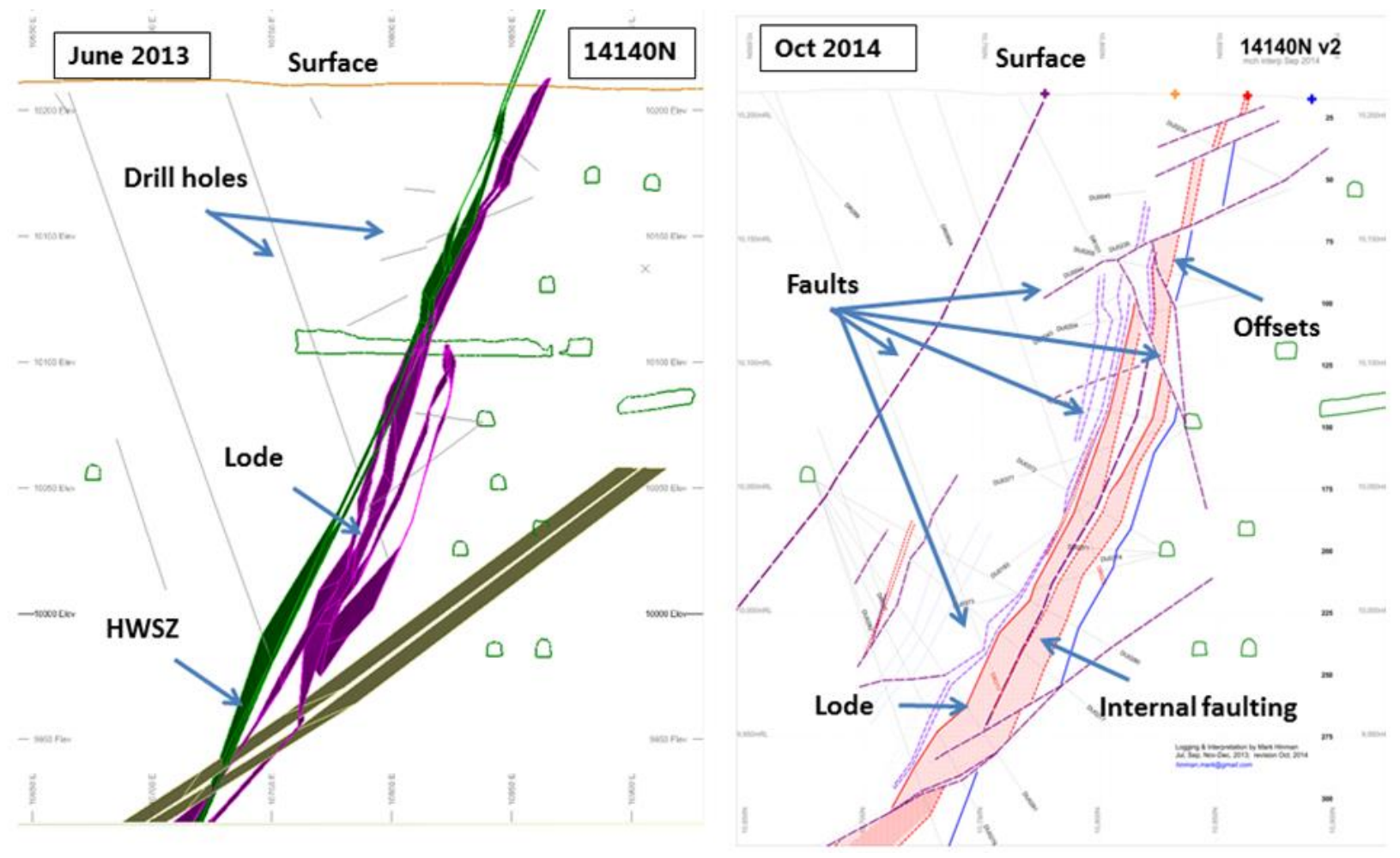

Figure 5 Section view of structural geology interpretation at $14140 \mathrm{mN}$ in June 2013 (left) and updated in October 2014 (right) showing much more complexity in structural geology 


\subsection{Rock stress and property measurements}

Two sets of stress measurements involving the installation and overcoring of seven CSIRO Cells were completed in the south mine in late 2013, prior to the commencement of trial stoping.

The first site stress measurements used three cells and took place at a depth of $162 \mathrm{~m}$ below the surface, in the FW limestone, near the south decline.

The second site stress measurement used four cells and was conducted at $220 \mathrm{~m}$ depth in slaty breccia and massive sulphide.

The stress measurements gradient were found to be consistent with the regional trend of data for the Mount Isa Inlier and the principal stress orientation was sub-parallel to the strike of the orebody (Table 1).

Table 1 Measured stress regime

\begin{tabular}{cccc}
\hline Principal stress & $\begin{array}{c}\text { Magnitude } \\
(\mathbf{M P a})\end{array}$ & $\begin{array}{c}\text { Dip } \\
\mathbf{(}^{\circ}\end{array}$ & $\begin{array}{c}\text { Dip direction } \\
\left.\mathbf{(}^{\circ}\right)\end{array}$ \\
\hline$\sigma_{1}$ & $6+(0.036 \times \mathrm{d})$ & 20 & 355 \\
$\sigma_{2}$ & $3+(0.025 \times \mathrm{d})$ & 12 & 88 \\
$\sigma_{3}$ & $(0.02 \times \mathrm{d})$ & 68 & 199 \\
\hline
\end{tabular}

\subsection{Intact rock property testing}

Intact rock property testing was completed as part of and previous to the 2012 Feasibility Study. Uncertainties with this data existed due to a lack of accurate supporting documentation, sample preparation and test method, hence they were highly questionable.

For this reason rock property testing was carried out in the trial stoping area. Samples were collected based on the following criteria:

- Freshly drilled.

- Bedding perpendicular to core axis (within $20^{\circ}$ ).

- Absence of structures.

- Within known geotechnical domains.

- NQ2 sized core.

The results from testing were reviewed and analysed by site geotechnical engineers. Tests found to have failed prematurely along foliation planes or bedding were discarded, providing a more accurate dataset (Table 2). This led to the rejection of all intact rock property testing prior to 2014. Comparisons of NQ2 sized core modulus to modulus results from the stress measurements provided good correlation. 
Table 2 Summary of the intact rock properties from laboratory testing

\begin{tabular}{|c|c|c|c|c|c|c|}
\hline & & & \\
\hline & & & $\begin{array}{l}U^{U C S}{ }_{50} \\
(\mathrm{MPa})\end{array}$ & $\begin{array}{c}\text { Young's } \\
\text { modulus } \\
(\mathrm{GPa})\end{array}$ & $\begin{array}{l}\text { Poisson's } \\
\text { ratio }\end{array}$ & $\begin{array}{l}\text { Uniaxial tensile } \\
\text { strength } \\
(\mathrm{MPa})\end{array}$ \\
\hline \multirow{6}{*}{ FW } & \multirow{3}{*}{ Slates } & Count & 4 & 2 & 2 & 3 \\
\hline & & Mean & 207 & 64 & 0.27 & 17.3 \\
\hline & & SD & 43 & 21 & 0.03 & 4.1 \\
\hline & \multirow{3}{*}{ Limestone } & Count & 9 & 7 & 7 & 7 \\
\hline & & Mean & 198 & 78 & 0.27 & 16.5 \\
\hline & & SD & 41 & 11 & 0.04 & 3.3 \\
\hline \multirow{6}{*}{ Lode } & \multirow{3}{*}{ Massive/breccia } & Count & 9 & 6 & 6 & 8 \\
\hline & & Mean & 189 & 73 & 0.29 & 10.0 \\
\hline & & SD & 75 & 8 & 0.02 & 1.2 \\
\hline & \multirow{3}{*}{ Slates } & Count & 2 & 2 & 2 & 1 \\
\hline & & Mean & 106 & 61 & 0.23 & 14.6 \\
\hline & & SD & 9 & 1 & 0.01 & - \\
\hline \multirow{3}{*}{ HW } & \multirow{3}{*}{ Slates } & Count & 7 & 4 & 4 & 3 \\
\hline & & Mean & 131 & 55 & 0.29 & 18.5 \\
\hline & & SD & 44 & 5 & 0.08 & 4.2 \\
\hline
\end{tabular}

\subsection{HW and development instrumentation}

A comprehensive geotechnical instrumentation program was designed and implemented to monitor and understand the rock mass response to mining. A variety of instrument types and measurement techniques were utilised (19, 10 and $6 \mathrm{~m}$ length multiple point extensometers, $3 \mathrm{~m}$ length single point resistance wire extensometers, cavity monitoring system, and time domain reflectometry cables). The focus of the instrumentation program was to analyse the rock mass response within the HW of the trial stopes (Figure 6 from Carswell et al. 2015). Instrumentation was also installed along oredrives and FW development areas to determine the extent of rock mass response relative to the stoping front. 

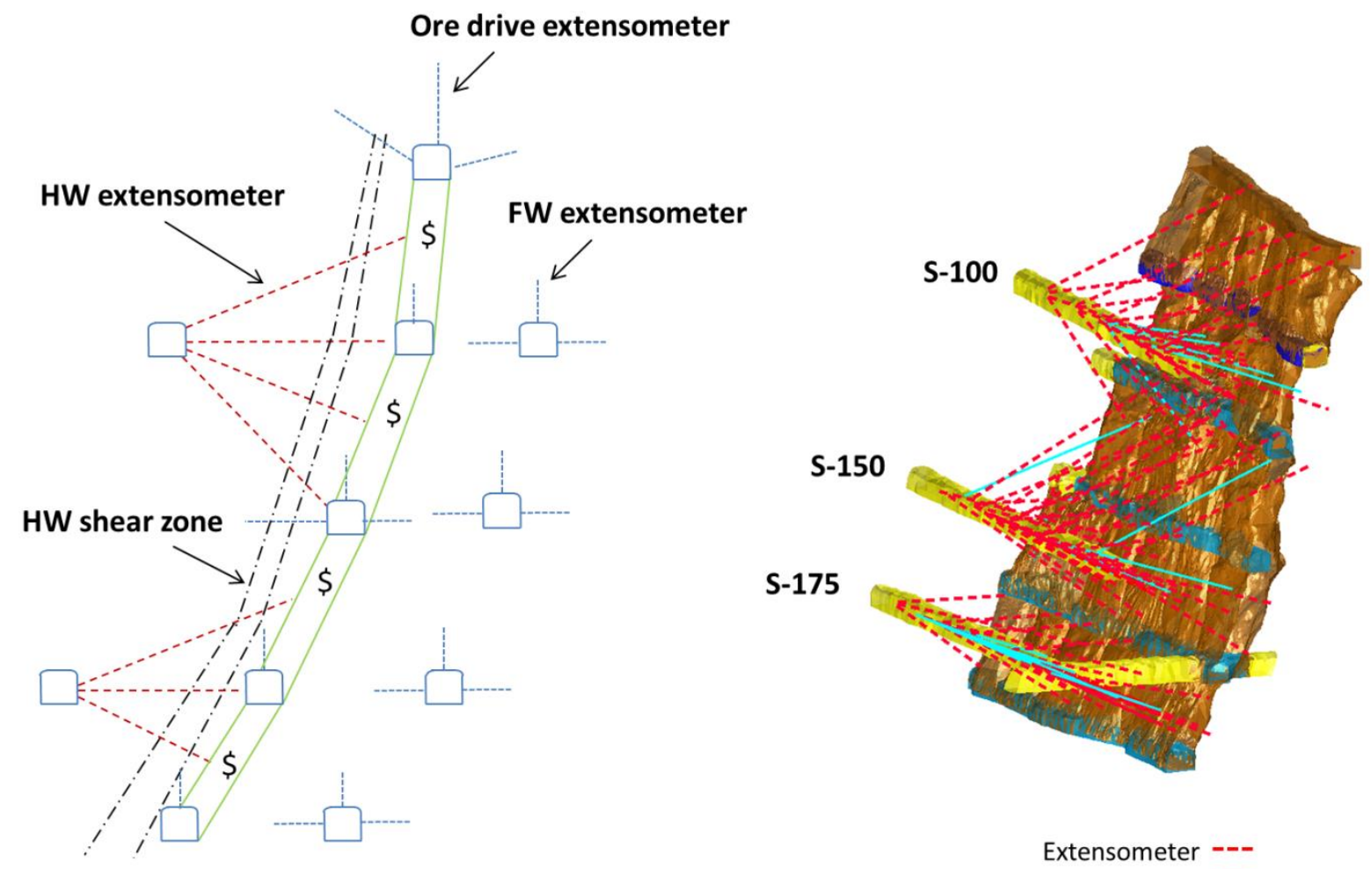

Extensometer --Observation hole -

Figure 6 Trial stoping instrumentation nominal section (left) and isometric view (right)

\subsection{Stope blast vibration monitoring}

Vibration monitoring was conducted on five stopes that were located in the centre of the trial stoping area (Figure 3). Vibration sensors were installed into the stope HW rock mass within the other instrumentation arrays. The key objective for blast vibration monitoring was to assess the extent of blast vibration damage and provide recommendations on drill hole orientation, ring burdens, stand-off distances, sequencing and timing to reduce rock mass blast damage (Hassell et al. 2015).

Surveying of production drill holes was carried out as a requirement for the stope blast vibration monitoring and for contractor performance indicators. At a minimum, breakthrough holes were surveyed. Additionally, select stopes had both breakthrough and non-breakthrough holes surveyed using a north seeking gyroscope. The survey data was then compared against the production drill design.

\subsection{Reconciliation of stope performance}

Each stope's geotechnical performance was reconciled across multiple categories:

- Actual mined stope shape compared against the design stope shape: stope wall instability controls would be determined considering the presence of geological structures, rock mass quality and drill and blast design.

- Ground support: the adequacy of stope wall ground support would be considered relative to the stope wall instability.

- Drill and blast: considered how the stope blasting was affected by internal faulting. As well as blasting effects on the stope wall overbreak or underbreak.

- Backfill: exposures would be assessed considering the designed fill strengths and drill and blast standoff considerations. 
- Specific learnings were obtained from visual inspections and operator feedback (drilling, charging and bogging). This information would be assessed and incorporated into the above categories as required.

The geotechnical stope performance data was used to develop the stope stability graph as a predictive tool for the Dugald River stoping performance.

Additionally, the operational data was reconciled:

- Production activity rates: bogging (remote and manual loader rates against tramming distance) and truck haulage against distance.

- Backfilling rates (tonnes per shift against tramming distance for loader).

- Drill and blast factors ( $\mathrm{t} / \mathrm{m}, \mathrm{kg} / \mathrm{t}$, charging time).

- Ore recovery and ore loss (\%).

The total reconciliation process would provide recommendations and improvements for future stope planning and design.

\subsection{Increasing stope strike length}

The initial five stopes were mined at $15 \mathrm{~m}$ strike lengths with minimal stability issues, exceeding expectations of stope wall stability. A decision was made to deviate from the initial trial stoping plan and to extend the stope size to further understand the rock mass performance. Select stopes were designed with increased strike lengths of up to $30 \mathrm{~m}$; additionally, some stopes were combined to create double lift stopes (Figure 7).

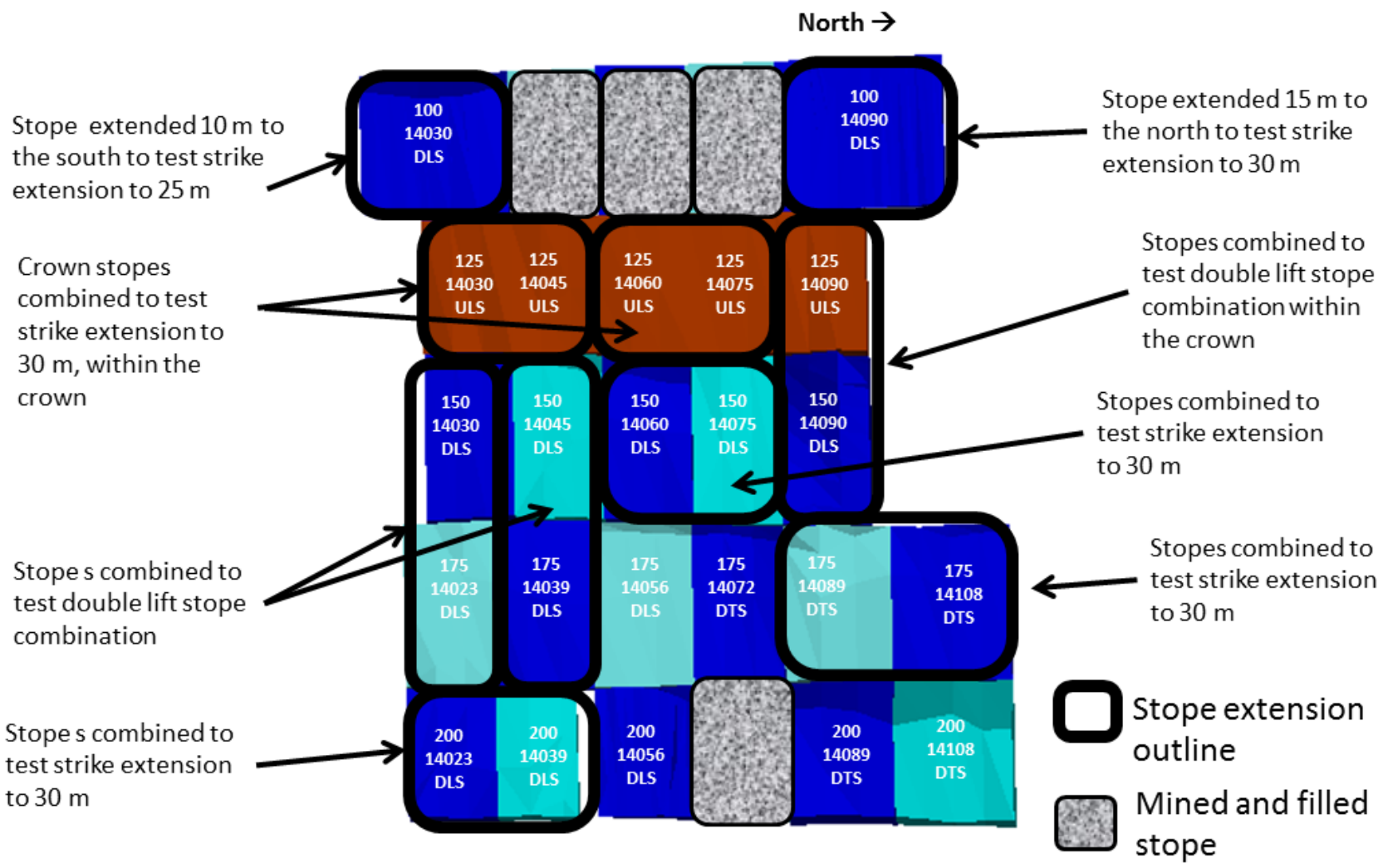

Figure 7 Schematic of Zone 6 looking west showing the remaining stopes and initial stope layout. Stopes identified for design changes are indicated 


\subsection{Cement rockfill optimisation}

A requirement of the SLOS mining sequence was a cemented backfill product to fill the stope void to provide a stable fill exposure when mining adjacent stopes. Backfill strengths of $500 \mathrm{kPa}$ for vertical exposures and 1,500 kPa for undercut exposures were determined (Mitchell et al. 1982; Terzaghi 1943).

CRF was selected as the preferred method due to availability of waste development rock, existing surface infrastructure and underground mining equipment. Waste rock at the mine is either non-acid forming (NAF) or potentially acid forming (PAF) which have loose densities of 1.7 and 2.1 respectively. The CRF used General Portland (GP) cement as the binder and a coarse aggregate product at $30 \%$ passing $10 \mathrm{~mm}$ with a top size of $150 \mathrm{~mm}$ (single pass through a jaw crusher).

Initial test work was completed on both crushed and uncrushed waste rock with and without the addition of sand and varying GP cement contents. Samples were cast in large UCS cylinders $(240 \mathrm{~mm}$ diameter and $490 \mathrm{~mm}$ height) and tested at the Western Australian School of Mines testing facility in Kalgoorlie. This test work determined that adequate strengths could be achieved with either rock type with $5 \%$ cement.

The crushed development waste rock was transported underground to specific mixing bays, where the GP cement slurry would be added and mixed with an underground loader. The loader would then place the material into the stope void.

Sample and test work was carried out as part of the backfill program using large cylinders (400 mm diameter and $800 \mathrm{~mm}$ height). A total of 56 samples were collected underground (Figure 8) and, after sufficient curing time, were transported to the Western Australian School of Mines testing facility in Kalgoorlie (Figure 8). As part of this testing program, the backfill was optimised by reducing cement contents for select stopes. Testing of these varying cement contents has successfully shown that cement content for vertical wall exposures can be reduced to $2.25 \%$ with PAF rock (Figure 9) and undercut exposures to $4 \%$ with NAF rock achieving the required strengths.
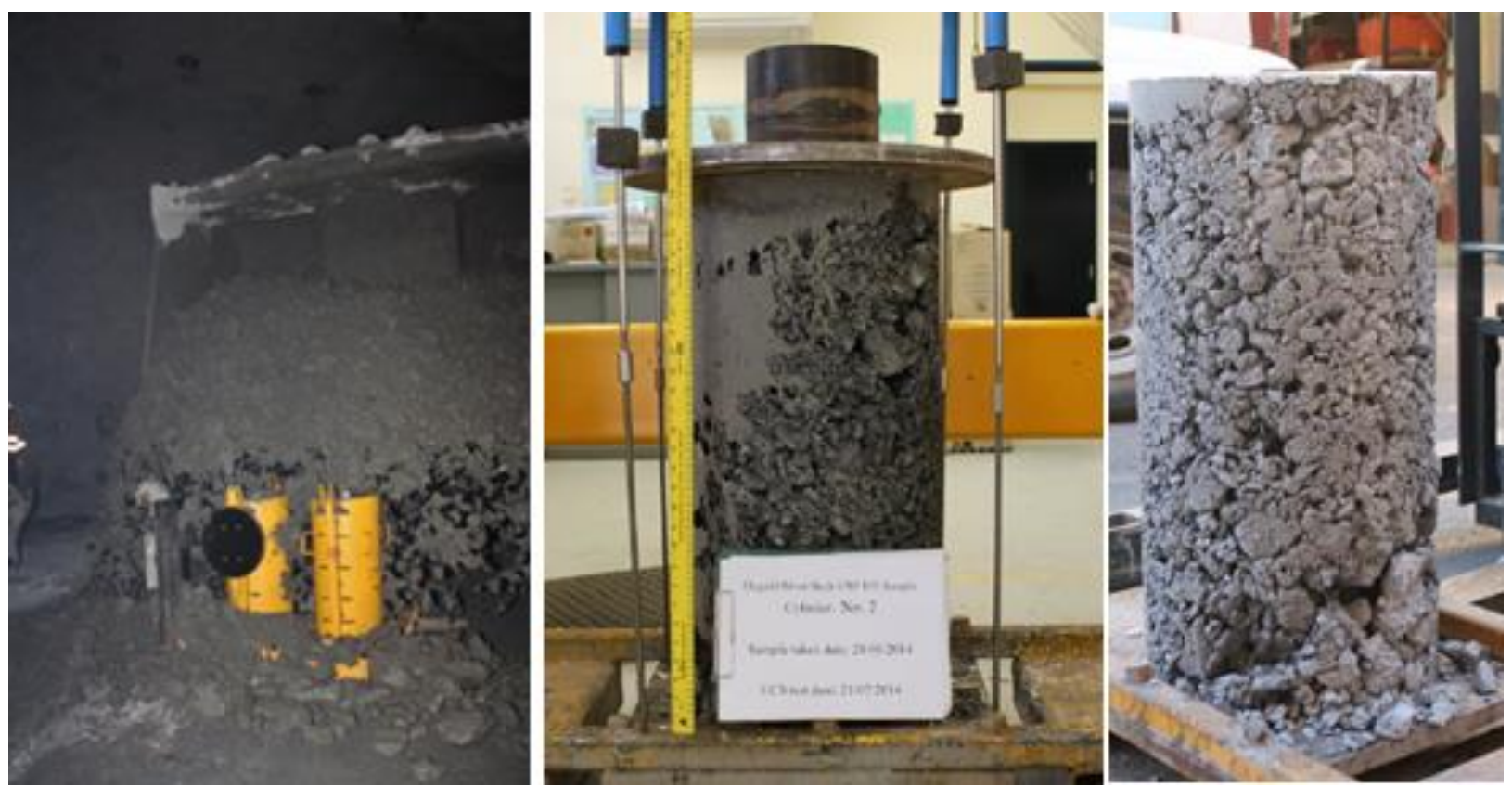

Figure 8 Sample collection and testing of $400 \mathrm{~mm}$ CRF cylinders 


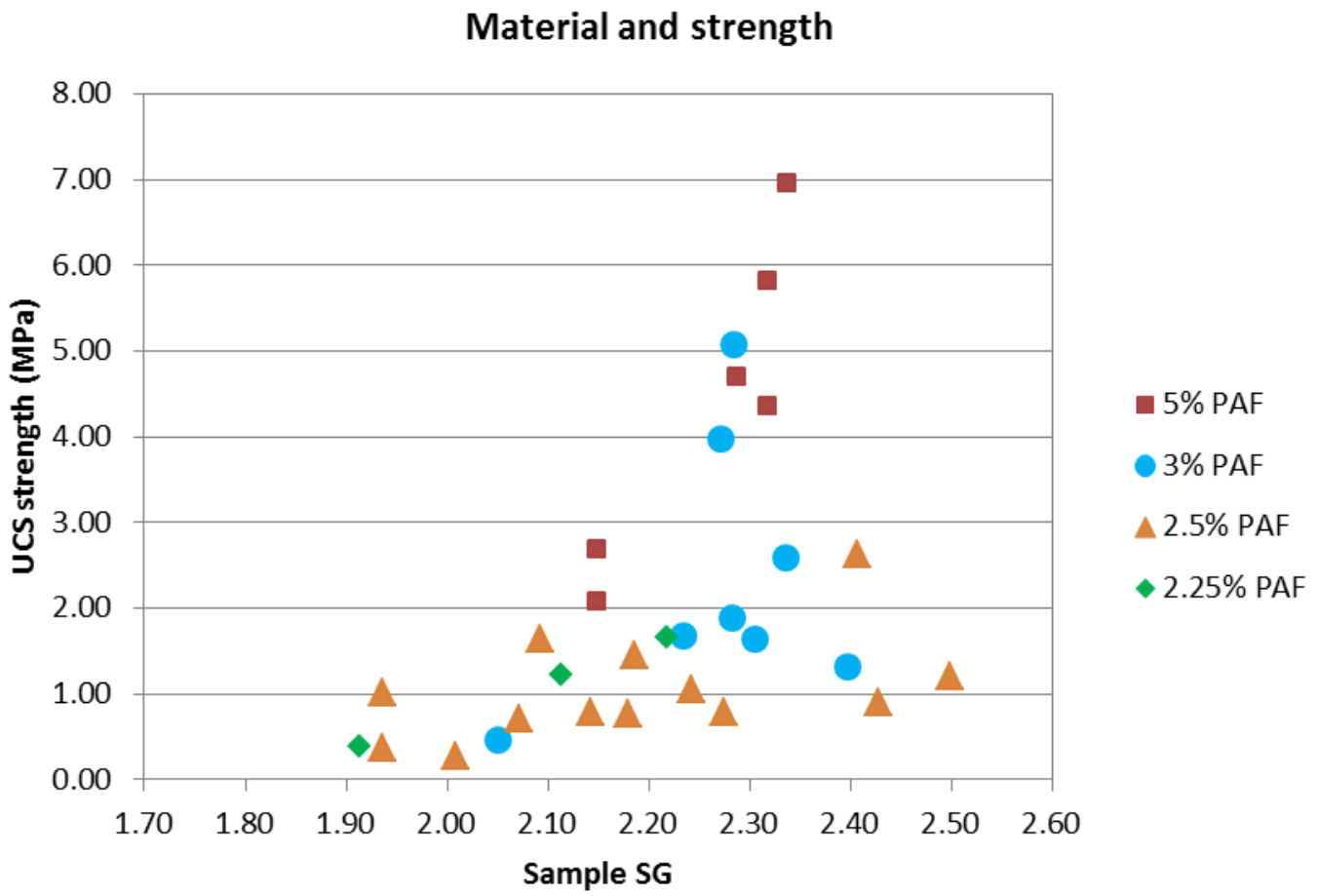

Figure 9 Graph of results for backfill testing with PAF material

Exposures of the backfill were observed and found to perform generally well (Figure 10). Overbreak of some backfill exposures was identified from surveying of the stope void. This overbreak was attributed to drill and blast effects rather than the stability of the fill. Banding of the fill mass was also visible from stope inspections, the effects of which will be discussed in Section 5.10.

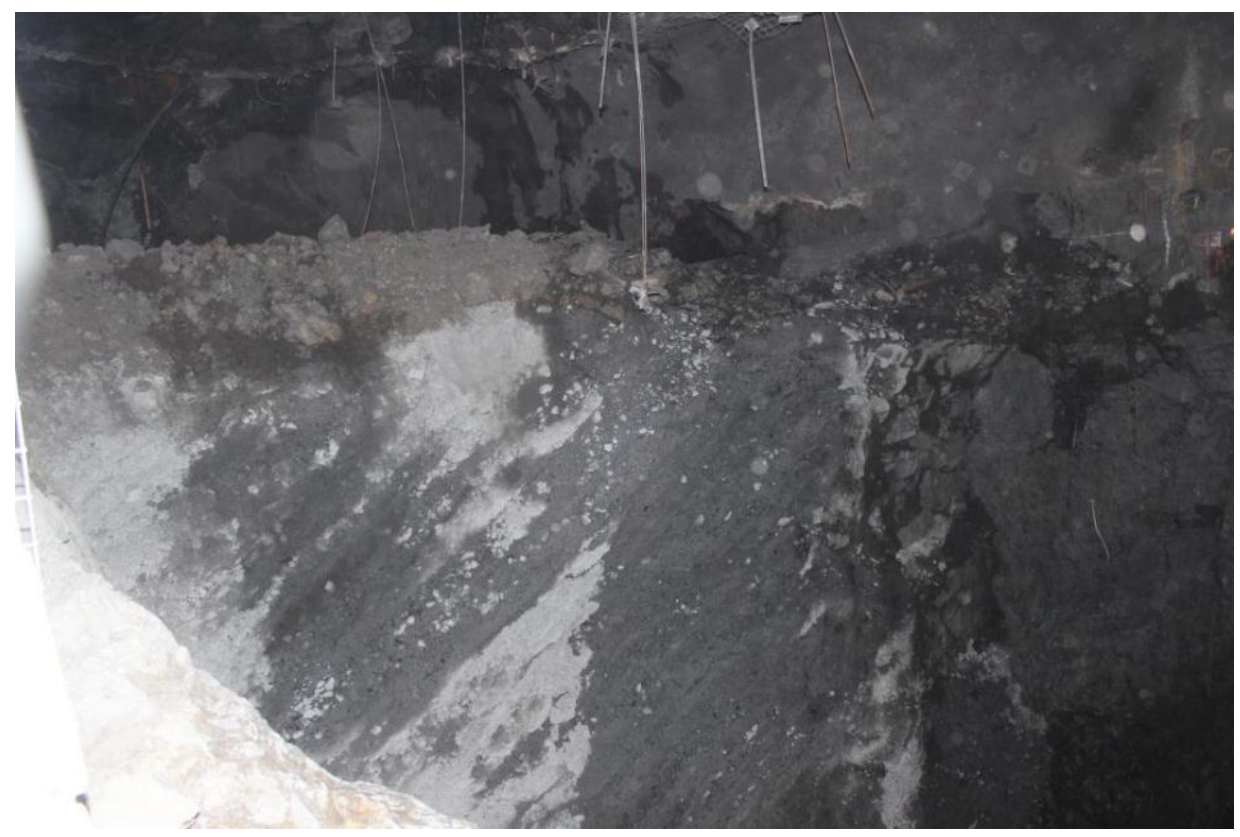

Figure 10 Photo of good performance of backfill exposure in upper wall of stope

\subsection{Development through CRF}

Horizontal development through the CRF was required to achieve maximum ore recovery of the crown stopes via down hole SLOS. Although development through the backfill was achieved successfully, there were many challenges, including: 
- Segregation of coarse material along the HW due to presence of individual stope cable bolts and placement of fill. This often resulted in lack of compaction of the fill. When developing through these areas, worm holes could occur.

- Banding of material as a result of lack of fines and/or operational issues, forming a non-homogenous fill mass (Figure 11).

- Unfavourable stope and development designs would create potential for slender wedges of backfill to be created, which were difficult to support.

Each of these challenges would result in unfavourable profiles being excavated which would generally require additional ground support and negatively impact development advance rates.

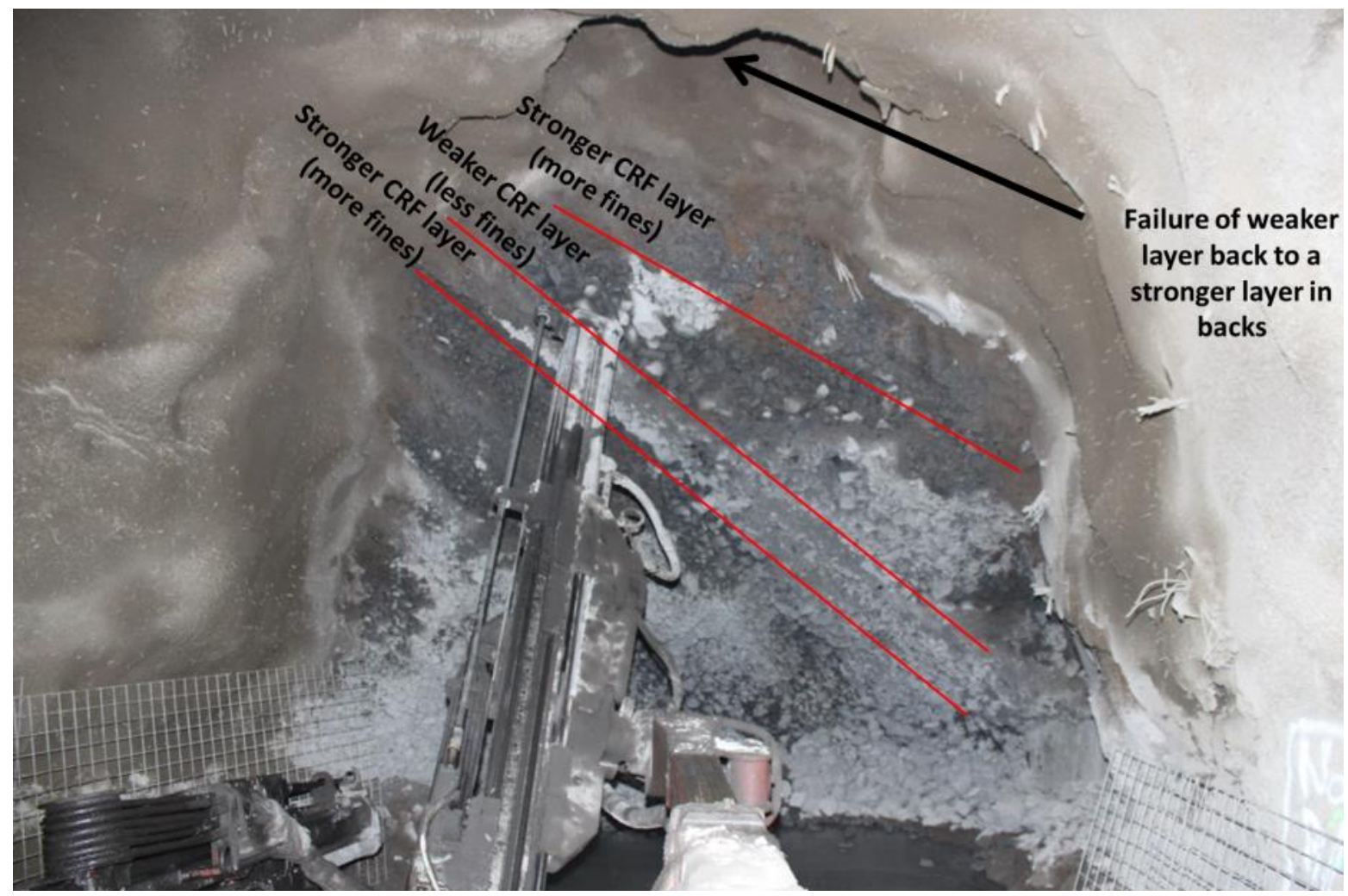

Figure 11 Banding in CRF when exposed during development

Reduced development advance from 4 to $2 \mathrm{~m}$ and the use of spiling bars in specific areas with a further reduction to $1 \mathrm{~m}$ advance proved beneficial to maintaining favourable profiles within the backfill.

The CRF development was undercut by stoping as the crown stopes were extracted. The undercut fill and development ground support performed well with minimal changes observed (Figure 12).

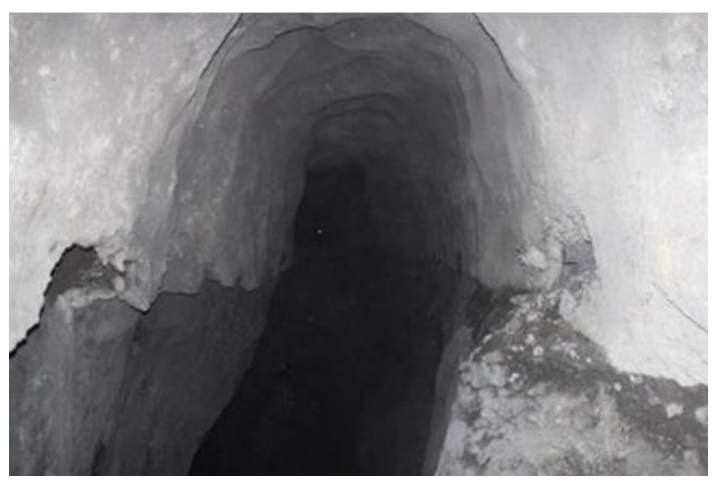

Figure 12 Extracted crown stope undercutting CRF filled stope 


\section{Updated geotechnical model for Dugald River}

The new standard of geotechnical core logging and the updated structural model provided an improved understanding of the rock mass conditions for mining at Dugald River. A reasonable correlation between the trial stoping performance and the model developed at the George Fisher Mine (Capes 2009) for estimating stope dilution could not be achieved (Figure 13).

\section{ELOS versus $\mathbf{N}^{\prime}$}

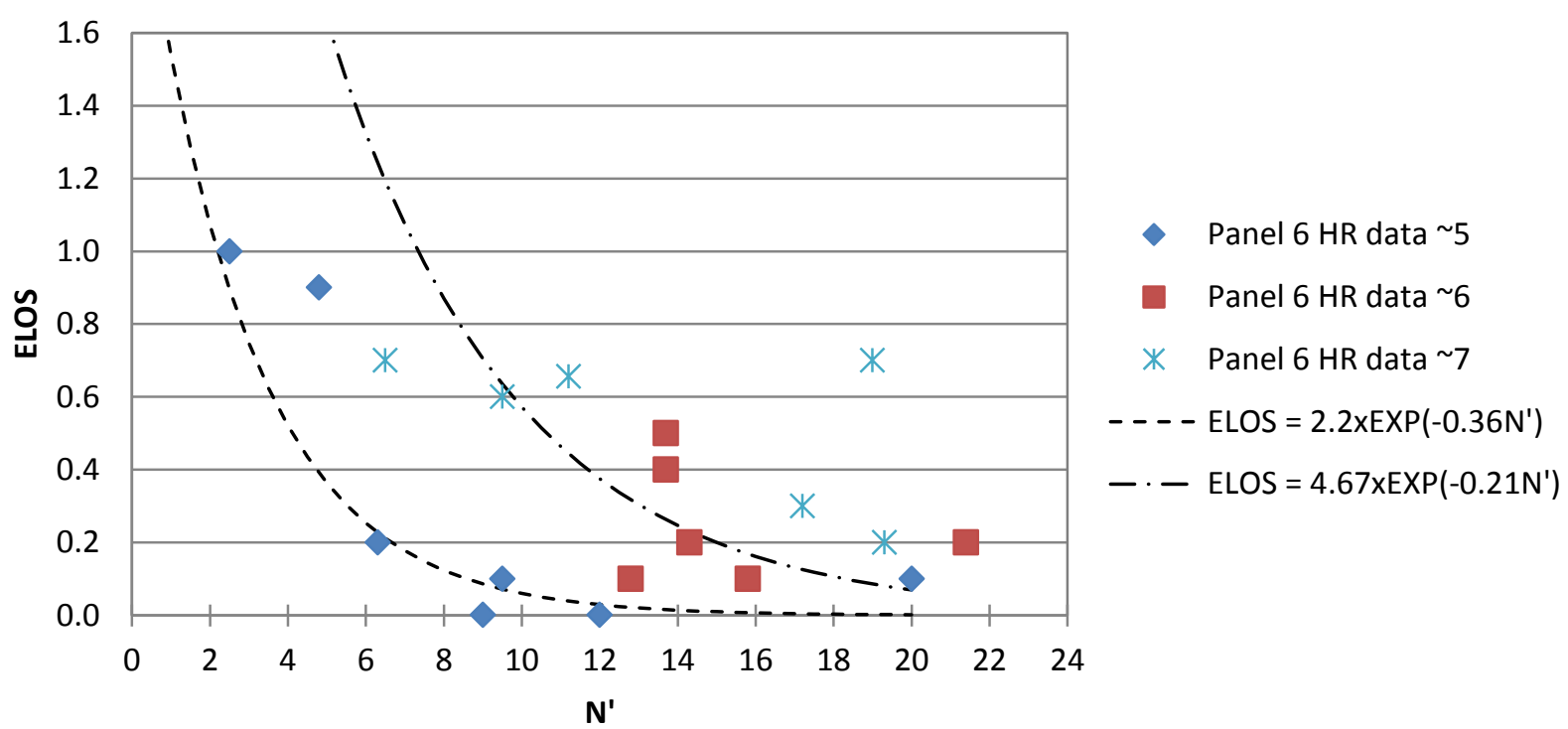

Figure 13 Graph of 19 trial stopes HW N' versus actual stope ELOS at varying HR values. The data does not correlate with formulas developed for specific HR at the George Fisher Mine (Capes 2009)

A new approach to improve the accuracy of overbreak forecasting was developed. The HW mechanistic overbreak model was established and calibrated using the additional geotechnical data ( 775 drill holes) and stope wall performance data from trial stoping. The model is more sensitive to the presence of weak rock layers in the HW, the main driving factor for stope stability at the mine. The process applies a geostatistical interpolation (ID2) to the rock mass in the stope HW collated into three bands, each $1.5 \mathrm{~m}$ thick, to determine a single category for the rock mass. The rock mass quality data examined is the minimum RQD within a band, $Q^{\prime}$ minimum within a band, and RQD average for a band. Surfer 10 from Golden Software was used for the geostatistics, data display and analysis. Twelve categories of mechanistic behaviours are determined for the HW. Dilution estimates were developed for each category based on the stope performance data from the trial stoping.

\section{$7 \quad$ Geotechnical design outcomes from trial stoping}

Improved confidence in the geotechnical input into the mine design has been developed from the various geotechnical studies conducted as part of the trial stoping project.

\subsection{Stope drill and blast parameter}

The stope blast vibration project determined the following improvements and recommendations for input into drill and blast practices to reduce rock mass damage from blasting (Hassell et al. 2015):

- HW production holes drilled parallel and at a $1 \mathrm{~m}$ standoff from the stope HW combined with low $0.8 \mathrm{~g} / \mathrm{cm}^{3}$ emulsion and increased delays limits HW overbreak. 
- Parallel and breakthrough holes reduce blast vibration damage. Confinement of blast holes by drilling of radial rings toeing or stabbing into the rock mass leads to higher vibrational energy yield which contributes to increasing overbreak.

- Where practical FW production holes to be drilled parallel to FW of stope boundary to reduce blast damage.

- Raise bored winzes did not provide any direct reduction in rock mass damage compared to conventional drill and blast winze.

- Production drill hole deviation analysis has highlighted the importance of quality control of production drilling including; equipment setup and drill site mark-ups.

\subsection{Oredrive and crosscut locations}

The placement of the oredrives is critical to reducing ore loss and stope wall instability. Prior to oredrive design, it has been stipulated by geotechnical engineers that all planned diamond drilling is to be completed, logged and analysed. Preliminary stope shapes are then required to be designed, considering the geological and geotechnical characteristics in the surrounding area. With the best available information, the oredrive design occurs and the development mined under survey control with geological and geotechnical checks on interpreted and actual conditions encountered.

The transition between longitudinal and transverse stopes is $11 \mathrm{~m}$ horizontal ore width. This was determined from a combination of analysis of mining costs (including ore loss from FW wedges and reduced development costs by not extending crosscuts to the FW access), scheduling considerations and drill and blast requirements for the parallel drilling of slot holes. FW wedges will be required for stability of the drill drives and future bogging horizons. Mining oredrives to widths greater than $7 \mathrm{~m}$ is not considered viable due to the potential for instability.

\subsection{Stope dilution estimates and varying stope strike lengths}

The new method of stope dilution estimation provides an average ELOS value of $1.5 \mathrm{~m}$ for the stope HW, with an improved confidence due to additional geotechnical and trial stoping performance data. Additionally, the use of ore skins to stabilise poor HW conditions have been significantly reduced, and the use of variable stope strike lengths $15-30 \mathrm{~m}$, which were successfully mined during the trial stoping, have been added. The average stope strike length is $20 \mathrm{~m}$, which is larger than the MMR, but shorter than the 2012 Feasibility Study. This has proven to be favourable to mine economics.

\subsection{CRF recommendations}

Current life-of-mine design requires the use of CRF in the upper areas of the mine until a paste backfill system becomes available. Backfill exposures observed during the trial stoping indicates an adequate product can be achieved for vertical exposures (crushed PAF waste rock with 2.25\% GP cement content) and undercut exposures (crushed NAF waste rock with 4\% GP cement content). Ongoing sampling and testing will be required to ensure an adequate product is being achieved.

\subsection{Improvements in development through CRF}

The design and operation of stopes that are situated above planned crown stopes requires consideration to future development through cemented backfill. These include:

- Oredrive and stope design needs to ensure minimal unfavourable geometries are created, such as undercutting of the oredrive HW. This may require ore loss in some cases to ensure favourable geometries are designed for safety and scheduling considerations.

- Ensuring all attempts are made to empty stopes, to avoid loose fill material being encountered during development. 
- Development through CRF at reduced advance rates to control overbreak and maintain profile.

- The use of spiling bars to control overbreak and maintain profile.

\subsection{Considerations of location of capital development}

Numerical modelling has been carried out with the site determined stress regime to assess the layout of capital development and infrastructure including FW drives, decline, ventilation raise bores, underground workshops and explosives magazines. This process has developed standoff distances relative to the orebody low grade FW contact. The standoff distances vary with depth as stress damage is expected.

\subsection{Ground support standards for development based on expected stress damage}

Numerical modelling was also carried out to assess expected rock mass response at varying depths to analyse ground support schemes for input into LOM. Observations from the trial stoping suggests that the site ground support standards of fibrecrete surface support and pattern bolting with solid rebar bolt performed adequately in a static low stress rock mass. Numerical modelling suggests that ground conditions are expected to be affected by mining induced stresses at a depth greater than $600 \mathrm{~m}$. Below this depth, increased ground support requirements have been included in the mine design, including additional surface support and reinforcement more suitable to high stress ground conditions.

\subsection{Stope sequencing and regional pillars}

The HW instrumentation identified that a step change in the rock mass response occurred when extracting the crown pillar stopes as the crown pillar restricted the overall HW interaction. This response would be expected to be enhanced with depth and stress increases, resulting in ore loss and productivity issues. To reduce this potential, a continuous panel sequence has been designed to avoid the formation of crown pillars, therefore forming an improved rock mass response, ultimately reducing ore loss and productivity issues. Stoping blocks will advance up and out toward regional pillars ensuring minimal creation of small pillars.

Regional pillars have been located at the natural abatement of grade and tonnage. Mining blocks will be advanced toward each of the regional pillars to avoid the formation of small close out pillars and potential ore and productivity losses (Figure 14). 


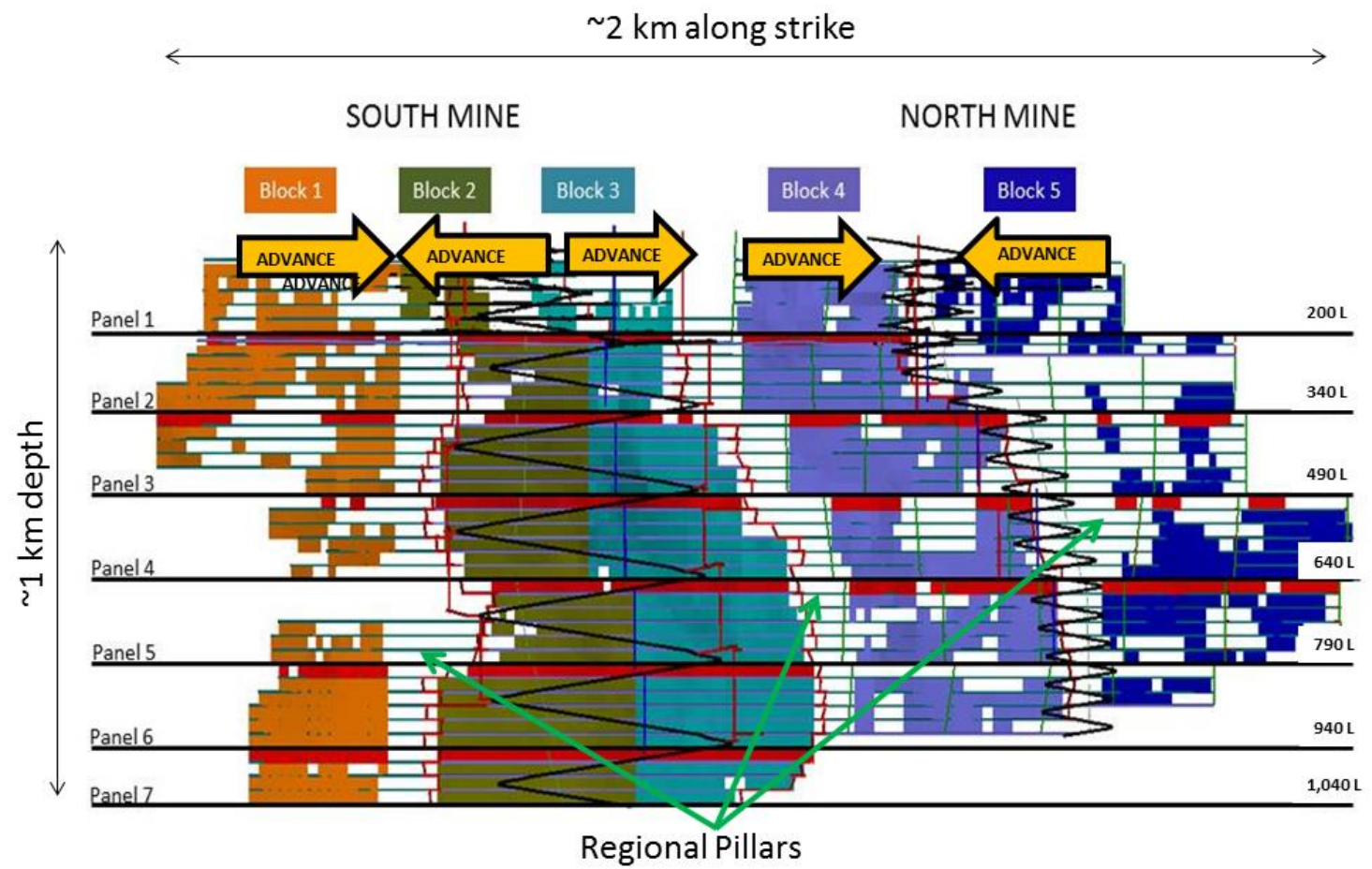

Figure 14 Long section of the Dugald River mining layout of panels and mining

\section{Conclusion}

The trial stoping project has successfully mined 19 SLOS for $355 \mathrm{kt}$ of ore at a $25 \mathrm{~m}$ sublevel interval and strike lengths from 15 to $30 \mathrm{~m}$, while maintaining stope HW overbreak within acceptable limits. Several geotechnical studies have been carried out as part of the trial stoping, providing a better understanding of the structural framework, updated geotechnical data and collection techniques and an improved process for estimating stope wall dilution. This has provided a higher confidence level for the geotechnical input into the mine design than previous studies. The trial stoping has highlighted the need for quality geotechnical data, established the process for gathering the data and specified the rules for successful stoping at the Dugald River mine.

\section{Acknowledgement}

The authors would like to acknowledge the MMG Limited's Dugald River Mine Geotechnical Department for their enthusiasm, assistance and input to all the studies carried out during the trial stoping project. The authors would also like to thank MMG Limited for permission to publish this paper.

\section{References}

Barton, N, Lien, R \& Lunde, J 1974, 'Engineering classification of rock masses for design of tunnel support', Rock Mechanics and Rock Engineering, vol. 6, no. 4, pp. 189-236.

Bieniawski, ZT 1989, Engineering rock mass classifications, John Wiley \& Sons, New York.

Capes, G 2009, 'Open stope hangingwall design based on general and detailed data collection in rock masses with unfavourable hangingwall conditions', PhD thesis, University of Saskatchewan.

Carswell, J, Player, J, de Vries, R, \& Hassell, R 2015, Sublevel open stoping hanging wall Instrumentation Program at the Dugald River underground mine, in PM Dight (ed.), Proceedings of the Ninth International Symposium on Field Measurements in Geomechanics, Australian Centre for Geomechanics, Perth, pp. 551-564.

Hassell, R, Villaescusa, E, de Vries, R, \& Player, J 2015, 'Stope blast vibration analysis at the Dugald River underground mine', Proceedings of the 11th International Symposium on Rock Fragmentation by Blasting (Fragblast 11), The Australasian Institute of Mining and Metallurgy, Melbourne.

Mitchell, RJ, Olsen, RS \& Smith, JD 1982, 'Model studies on cemented tailings used in mine backfill', Canadian Geotechnical Journal, vol. 19, pp. 14-28.

Terzaghi, K 1943, Theoretical soil mechanics, John Wiley \& Sons, Inc., New York, NY. 